Araştırma Makalesi - Research Article

\title{
COVID-19 Salgınında Alınması Gereken İş Sağlığı ve Güvenliği Önlemleri
}

\section{Occupational Health and Safety Measures To Be Taken in the COVID-19 Pandemic}

\author{
Gaye BAYCIK * \\ (iD) 0000-0002-1098-6948 \\ Özlem TÜRKŞEN** \\ (iD) 0000-0002-5592-1830 \\ İstemi Ceysu DİNÇ*** \\ (iD) 0000-0002-5345-5899 \\ ÖZ
}

Salgınlarda işyerlerinde alınan iş sağlığı ve güvenliği (ISSG) önlemleri, toplum sağlığının korunmasında hayati öneme sahiptir. Çalışmamız kapsamında, uluslararası kuruluşların ve gelişmiş ülkelerin İSG konusundaki rehber ve uygulamaları değerlendirilerek, COVID-19 ve solunum yoluyla bulaşın gerçekleştiği benzer nitelikli bir salgında işyerlerinde alınması gereken önlemler belirlenmiştir. Uluslararası kaynaklardan ve değerlendirmelerden elde ettiğimiz bilgilerle tespit edilen önlemlerin ülkemizde uygulanması bakımından halihazırdaki durum, TÜBITTAK 120K619 sayılı Projemiz kapsamında gerçekleştirdiğimiz anket sonuçlarının istatistiki incelemesiyle belirlenmiştir. $\mathrm{Bu}$ itibarla çalışmamızda projemiz kapsamında gerçekleştirdiğimiz kapsamlı anketlerden elde ettiğimiz veriler kullanılarak, öncelikle ülkemizde salgın döneminde alınan yaygın ek ISG önlemleri tespit edilmiş; ardından ülkemizdeki işyerlerinde hangi önlemlerin alınmadığ 1 veya çok az alındığı belirlenmiştir. Son olarak, salgınla etkin mücadelede işyerlerinde alınması gereken İSG önlemleri açıklanmış ve ülkemizdeki eksikliklerin bu öneriler doğrultusunda tamamlanması amaçlanmıştır.

Anahtar Sözcükler: COVID-19, salgın, iş sağlığ1 ve güvenliği, pandemi
Sosyal Güvenlik Dergisi / Journal of Social Security

ayfa Aralığı: 17-32 / Pages:17-32

OI: 10.32331/sgd.952506

Önerilen atıf şekli: Baycık,G., Türkşen, Ö. ve Dinç, İ. C. (2021). COVID-19 Salgınında Alınması Gereken İş Sağlığı ve Güvenliği Önlemleri. Sosyal Güvenlik Dergisi (Journal of Social Security). 11(1). 17-32

• Geliş Tarihi/Received: 06/04/2021 • Güncelleme Tarihi/Revised: 01/06/2021 • Kabul Tarihi/Accepted: 14/06/2021

\footnotetext{
* Doç. Dr., Ankara Üniversitesi Hukuk Fakültesi, İş ve Sosyal Güvenlik Hukuku Anabilim Dalı, gbaycik@law.ankara.edu.tr

** Doç. Dr., Ankara Üniversitesi Fen Fakültesi, İstatistik Bölümü, turksen@ankara.edu.tr

*** Arş. Gör., Yozgat Bozok Üniversitesi Hukuk Fakültesi, İş ve Sosyal Güvenlik Hukuku Anabilim Dalı, istemiceysu.dinc@bozok.edu.tr
} 


\section{GíRiş}

COVID-19, Dünya Sağlık Örgütü tarafından pandemi olarak ilan edilmiş ve hayatın her alanını yoğun bir biçimde etkisi altına almıştır. Salgın, bugüne kadar ticari işlem kalıplarında yarattığı değişiklikler, tedarik zincirlerinde yaşanan aksaklıklar, çalışanların işe devamsızlığ ve uygulanan kısıtlamaların işletmelerin sürdürülebilirliğini zorlaştırması başta olmak üzere, çalışma yaşamını ve işyerlerini büyük ölçüde etkilemiştir. COVID-19'un tamamen kontrol altına alınana dek çalışma yaşamı üzerindeki etkilerini sürdürmeye devam edeceği açıktır (U.S. Department of Labor Occupational Safety and Health Administration, 2020: 6).

COVID-19 pandemisi öncesinde yaşanan kuş gribi, domuz gribi, ebola gibi salgınlardan elde edilen deneyimler, salgının kontrol altına alınması ve nihayetinde tamamen sonlandırılmasında, işyerlerinin merkezi bir öneme sahip olduğunu ortaya koymuştur. $\mathrm{Bu}$ nedenle işyerlerinde COVID-19 ve benzer nitelikli salgınlar bakımından alınması gereken İSG önlemlerinin etkin şekilde uygulanması, yalnızca çalışanların sağlığının korunması ve işverenin sorumluluğu açısından değerlendirilebilecek bir husus değil, aynı zamanda bir toplum sağlığı meselesidir (Berkowitz, 2020).

Çalışmamızın ilk bölümünde; COVID-19 pandemisi karşısında ülkemizdeki işyerlerinin halihazırdaki durumu değerlendirilmiştir. Bunun için, projemiz kapsamında gerçekleştirdiğimiz ve salgında faaliyetine devam eden bakanlık, üniversite, banka, çağrı merkezi ve sigorta şirketi çalışanı olan 998 kişiye ve bu işyerlerinin işveren ve üst düzey işveren vekili konumunda olan 201 kişiye uygulanan anketten elde edilen verilerin istatistiki sonuçları kullanılmıştır. $\mathrm{Bu}$ anketlerden elde ettiğimiz veriler, ülkemizdeki işyerlerinin COVID-19 karşısındaki İSG durumunu ortaya koymamıza, dolayısıyla hem halihazırda alınan ISG önlemlerinin tespitine hem de alınmayan veya yeterli seviyede ve yeterli işyerinde alınmayan İSG önlemlerinin belirlenmesine öncü olmuştur. Bu şekilde çalışmamızın ilk bölümünde ülkemizde yaygın şekilde alınan ISSG önlemleri, ikinci bölümünde ise ülkemizde yeterli düzeyde alınmayan İSG önlemleri açıklanmıştır.

Çalışmamız üçüncü bölümünde ise, ülkemizdeki işyerlerinde COVID-19 karşısında alınması gereken önlemler ve yapılması gerekenler hakkında açıklayıcı bilgiler verilerek, araştırmalarımızdan elde ettiğimiz veriler ve bilgiler ışığında politika yapıcılara ve uygulamada işverenlere naçizane bir yol oluşturulmaya çalışılmıştır. Bu amaçla, Uluslararası Çalışma Örgütü'nün hazırladığı rehberler başta olmak üzere, uluslararası kuruluşlar ve gelişmiş ülkeler tarafından COVID-19 ve benzer nitelikli bir salgında işyerlerinde alınması gereken ISG önlemlerine ilişkin hazırlanan rehber ve uygulamalar değerlendirilmiş; sonucunda işyerlerinde alınması gereken başlıca İSG önlemleri tespit edilmiştir.

\section{I- ÜLKEMIZDE COVID-19'A KARŞI YAYGIN ŞEKILLDE ALINAN EK İSG ÖNLEMLERI}

COVID-19 ve benzer şekilde solunum yoluyla bulaşın gerçekleştiği salgınlarla mücadelede, çalışanların çoğunlukla bir arada bulunması nedeniyle işyerlerinde İSG önlemlerinin alınması, toplum sağlı̆̆ açısından hayati öneme sahiptir. Bilindiği üzere, COVID-19 ve benzer nitelikli salgınlarda, işyerindeki mevcut İSG önlemlerine ek olarak, salgının yayılımının önlenmesi için, bilim ve teknolojinin elverdiği ölçüde gerekli olan her türlü " $e k$ önlem" alınmalıdır. Bu itibarla, salgın özelinde risk değerlendirmesi yapılmalı, bulaşın önlenmesi için ek İSG eğitimleri verilmeli, bulaşa neden olan etkenlerle ilgili bilgilendirme yapılmalı, dönüşümlü çalışmaya geçilmeli, toplu şekilde ve yakın mesafe çalışma önlenmeli, havalandırma en üst düzeye çıkarılmalı, maske, siperlik, dezenfekte edici sıvılar tüm çalışanlara yeteri miktarda sağlanmalıdır. Aşağıda bunların detaylarına yer verilecektir. 
Gerçekleştirmiş olduğumuz araştırmalar sonucunda elde edilen veriler, ülkemizde salgının niteliğine uygun bazı "ek önlemler"in yaygın şekilde alındığını göstermektedir. Nitekim, işyerlerinde çalışanlara yöneltilen "COVID-19 vakasının ilk kez görüldügü 11 Mart 2020 tarihinden sonra, işyerinizde COVID-19'a karşı ek ISG önlemleri alındı mı?” sorusuna araştırmaya katılanların \%89,78'i "Evet" ve \%10.22'si "Hayır" yanıtını vermiştir. "Sizce çalıştı̆̆ınız işyerinizde alınan ek ISG önlemleri yeterli midir?" sorusuna ise araştırmaya katılanların \%58,87'si "Evet" ve \%41,13'ü "Hayır" yanıtını vermiştir. Bu itibarla, araştırmamız kapsamına dahil edilen işyerlerinde çalışanların \%58,87'sinin, salgından kaynaklı risklere yönelik ek İSG önlemlerinin yeterli biçimde alındığını ifade ettiğini belirtmek yanlış olmayacaktır.

Aynı soruların işverenlere ve üst düzey işveren vekillerine yöneltilmesi sonucunda, işverenlerin \%89,55'i, salgın dolayısıyla ek İSG önlemleri aldığını ifade etmiştir. Araştırmaya katılan işverenlerden \%8,96'sı kısmen ek önlemlere başvurduğunu, \%1.49'u ise salgın kaynaklı hiçbir ek İSG önlemi almadığını beyan etmiştir. Kendilerine yönettiğimiz "Salgın hastalı nedeniyle ISG önlemleri maddi olarak sizi zorladı mı?" sorusuna ise işverenlerin \%60,73’ü "Hayır", \%28,80'i “Kısmen” ve \%10.47'si "Evet" yanıtlarını vermiştir. Ek İSG önlemlerinin kendini zorladığını ifade eden işveren/işveren vekillerinin işyerlerinin \%9,2'si banka, \%8'i kamu kurumu ve \%17,2'si üniversitedir.

Genel olarak tüm çalışanlar için alınması gereken ek ISSG önlemleri yanında, COVID-19’a karşı diğerlerine nazaran daha dayanıksız olan çalışan gruplarının, yaş, hastalık öyküsü gibi özel durumlarının ayrıca göz önünde tutulması gerektiği açıktır. (T.C. Sağlık Bakanlığı, 2020a; Canadian Centre of Occupational Health and Safety, 2020). Bu doğrultuda gerçekleştirdiğimiz araştırmalarda, işverenlerin \%56,21'i, kronik hastalığı bulunan veya belirli bir yaşın üstündeki çalışanlarını uzaktan çalışmaya geçirdiğini; \%21.39'u, söz konusu çalışanların yıllık izin sürelerini bu dönemde kullandırdığını; \%8.45'i ise bu nitelikteki çalışanlarını ücretsiz izne çıkardığını ifade etmiştir. Kamu personeli açısından ise idari izin uygulaması, kronik hastalığı bulunanalar ve 60 yaş üstündekiler açısından uygulama alanı bulmuş, bu şekilde kamu çalışanlarında da özel durumu olan kişiler bu şekilde korunmuştur.

COVID-19'un bulaşma yönteminin temelinde damlacık solunması ve el hijyenine dikkat edilmemesi olduğu gerçeği karşısında, ülkemizdeki işyerlerinin çoğunda buna ilişkin bilgilendirici metinlerin işyeri duvarlarına asıldığı ve damlacık yayılımını, dolayısıyla çalışanlar arası teması ve çalışan yoğunluğunu engellemeye yönelik önlemler ile el hijyenine yönelik önlemlerin alındığı tespit edilmiştir.

Araştırmalarımız kapsamında, çalışanların \%53,70'i işyerinde afiş, broşür, ilan, e-mail vb. yoluyla bu konularda ek bilgilendirme yapıldığını; \%71,54'ü ise, el hijyenine yönelik ek önlemler alındığını ifade etmiştir. Araştırmalarımıza katılan işverenlerin ise \%62,68'i işyerinde afiş, broşür, ilan, e-mail vb. yoluyla ek bilgilendirme yaptıklarını \%90,54'ü el hijyenine yönelik ek önlemler aldıklarını beyan etmiştir. Buna göre, çalışmaya dahil edilen işyerlerinin büyük çoğunluğunda, dolayısıyla ülkemizdeki işyerlerinin büyük kısmında, damlacık solunması ve el hijyeniyle ilgili ek önlemlerin yeterli düzeyde alındığı ve bilgilendirmelerin yeterli şekilde yapıldığı sonucuna varmış bulunmaktayız.

Solunum yoluyla bulaşan COVID-19 gibi salgınlarda, sadece işyerinde çalışmak için bulunana değil, işyerine çalışmak için olmasa dahi, gelenler bakımından da birçok kural getirilmesi gerektiği açıktır. İşyerinde bulunan her bireyin, potansiyel COVID-19 taşıyıcısı olduğu düşünülmeli ve buna göre hareket edilmelidir. Bu itibarla, solunum sıkıntısı, öksürük, $38^{\circ} \mathrm{C}$ 'den yüksek ateş, koku kaybı, eklem ağrısı ve diğer COVID-19 hastası belirtileri olanlar ile teşhis konanların ve temaslıların işyerine alınmayacağı ve COVID-19 belirtileri olanların derhal bir sağlık kurumuna yönlendirileceği yönündeki kuralların hem işyerinde çalışanlara 
hem de işyerine gelen herkese uygulanacağı bilgilendirici ilan ve afişlerde yer almalıdır ${ }^{1}$. Gerçekleştirdiğimiz araştırmaya katılan çalışanların \%39,17'sinin, işverenlerin ise \%52,23'ünün, ateş ölçer gibi kontrol yöntemleriyle işyerine dışarıdan bulaş gelmesini önleyici önlemlerin alındığını belirttikleri görülmüştür.

Ek İSG önlemlerinden bir diğer olan sosyal temasın azaltılmasına yönelik olarak, çalışmamız kapsamındaki çalışanların \%69,23'ü işyerinde sosyal mesafeyi azaltmaya yönelik önlemlerinin alındığını; çalışanların \%19.33'ü ise, bu şekilde önlem alınmadığını, ancak sosyal mesafe önlemlerinin alınmasının gerekli olduğunu ve bunu istediklerini ifade etmiştir. Bunun gibi, çalışanların \%49,89'u işyerine ziyaretçi/müşteri giriş yasağı veya sayı sınırlaması getirildiğini; \%18,33'ü ise sayı sınırlaması getirilmesini istediğini belirtmiştir. İşyerlerinde sayı sınırlaması getirildiğini ifade eden çalışanlardan \%44,2'si banka çalışanı, \%25,9’u kamu kurumunda idari personel, \%10,2'si üniversitede idari personelidir. Araştırmamızdaki çalışan gruplarının sadece \%69,23’ü sosyal mesafe önlemlerinin alındığını belirtmişken, araştırmamıza katılan işverenlerin \%90,54'ü işyerlerinde sosyal mesafe önlemlerini aldıklarını ifade etmiştir. $\mathrm{Bu}$ oran arasındaki büyük fark, ülkemizdeki gerçekleştirilen anketlere verilen cevapların doğruluğu konusunda açıkçası tarafımızda endişe yaratmıştır.

Görüldügü üzere COVID-19 salgınının ortaya çıkmasıyla birlikte ülkemizde işyerlerinde belirli farkındalıklar oluşmuş, gerekli olan bazı ek ISG önlemleri alınmış, bilgilendirme faaliyetleri yürütülmüştür. Ancak bu önlemlerin, hem tüm işyerlerinde tam anlamıyla alınmaması nedeniyle yeterli olmadığı, hem de ülkemizde alınan önlemler yanında alınması gereken başkaca önlemler bulunması nedeniyle yetersiz olduğu aşağıda yapılan açıklamalar sonucunda varılacak olan sonuçtur.

\section{II- ÜLKEMIZ ISSYERLERINDE COVID-19 ÖNLEMLERINNDEKİ EKSİKLİKLER}

Risk değerlendirmesi, iş sağllğ 1 ve güvenliğinin sağlanmasında "ilk temel adım " niteliği taşır. Zira risk değerlendirmesi, o işyerinde iş kazası veya meslek hastalığına neden olabilecek her türlü tehlike, bu tehlikeyi riske dönüştüren faktörler ve riskin gerçekleşme oranı ve gerçekleşmesi halinde ortaya çıkaracağı zararın boyutu ve frekansı belirlenir. Bu nedenle risk değerlendirmesi, her yeni risk durumunda veya her risk gerçekleşmesi ve hatta ramak kala olayda dahi yenilenmesi gereken bir adımdır.

COVID-19 gibi hızla ve kolaylıkla bulaşma özelliği bulunan virüsün salgın yaratması durumunda, işverenlerin, halihazırdaki risk değerlendirmelerinin yetersiz kalacağ 1 açıktır. Bu nedenle salgın özelinde yeni bir risk değerlendirmesi yapılmalı ve bunun sonucunda alınması gereken önlemler tespit edilerek ayrıca bir acil durum eylem planı hazırlanmalıdır (World Health Organization, 2020a; U.S. Department of Labor Occupational Safety and Health Administration, 2020: 7-8).

Ülkemizde salgın özelinde yeni risk değerlendirmesinin ne yazık ki çok az sayıdaki işyerinde yapıldığı araştırmalarımız sonucunda tespit edilmiştir. Zira araştırmaya katılan çalışanların yalnızca \%11,62'si, salgın sonrasında işyerinde risk değerlendirmesinin güncellendiğini belirtirken; acil durum eylem planının gözden geçirildiğini ise sadece \%11,82'si ifade etmiştir. Benzer şekilde araştırmamıza katılan işverenlerin yalnızca \%19,40’1 salgın sonrasında işyerinde risk değerlendirmesinin güncellendiğini belirtirken, aynı şekilde

Çalışanlar tarafından mümkün olduğunca işyerine girmeden önce veya randevu alırken müşterilere hasta olup olmadıkları veya COVID-19 semptomları olup olmadıkları sorulmalı ve hasta olan müşterilerden işyerine girmemeleri istenmelidir (T.C. Sağlık Bakanlığı, 2020b; Goverment of Canada, 2020). 
işverenlerin sadece \%19,90'1, işyerindeki acil durum eylem planının gözden geçirildiğini ifade etmiştir. Bu itibarla, salgın özelinde risk değerlendirmelerinin ülkemiz açısından büyük eksiklik olduğunu belirtmek gerekir.

İşyerinin güvenli ve çalışanların sağlığı açısından tehdit oluşturmayan bir yapıya kavuşması için işveren tarafından tek taraflı olarak belirlenen önlemlerin empoze edilmesi yeterli değildir. Gereken önlemlerin ihtiyaçları karşılayacak biçimde, doğru, etkin ve çalışanlar tarafından uyulabilir şekilde belirlenmesi için işyerinde İSG bilincinin oluşması ve çalışanların bu sürecin paydaşı olması gerektiği açıktır. Salgın özelinde işyerindeki kıdemli yöneticilerden, danışmanlardan, işçi temsilcilerinden ve işyerinin sorumlu İSG personelinden oluşturulması gereken pandemi kurulu ya da atanacak pandemi temsilcisi, işyerinde bu etkileşimi sağlamaya yönelik uygulamalardan biridir (International Labour Organization, 2009: 16). Buna karşılık araştırmamızda yer alan çalışanların yalnızca $\% 8,71$ 'i, işyerinde pandemi kurulunun oluşturulduğunu; \%4,70'i ise sadece pandemi yetkilisinin atandığını ifade etmiştir. Aynı şekilde, araştırmamızdaki işverenlerin de sadece \%7,96'sı, işyerinde pandemi kurulunu oluşturduklarını; \%5, 47'si ise sadece pandemi yetkilisi atadığını ifade etmiştir. İşveren ve işveren vekillerinin beyanları doğrultusunda pandemi kurulunun oluşturulduğu işyerlerinin \%62,5'i banka, \%18,8'i kamu kurumu, \%18,8'i üniversitedir. Bunun gibi pandemi yetkilisinin atandığı işyerlerinden de \%54,5'inin banka, \%27,3'ünün kamu kurumu, \%18,2'sinin ise üniversite olduğu tespit edilmiştir. Bu sayıların oldukça düşük olduğu açıkça görülmektedir.

İşyerinde İSG bilincinin oluşması ve çalışanlarda salgın konusunda da farkındalık yaratılması için en önemli adım, salgın özelinde İSG eğitiminin verilmesidir (Süzek, 2020: 892; Özdemir, 2014: 288; Öztürk, 2015: 30). Zira çalışanlarda bu konuda İSG bilinci, ancak salgına yönelik ek İSG önlemlerinin önemini, nedenini ve amacını öğrenmesiyle oluşabilir. İşyerlerinde salgına yönelik hazırlanacak İSG eğitimi konuları arasında; virüsün nasıl yayıldığı, virüsten korunma yolları, dezenfektanların kullanımı ve yan etkileri, maske kullanımı, maskenin değişim süresi, maskenin atılma yöntemi, siperlik kullanım kuralları, sosyal mesafe, hastalık belirtileri, hastalığın bulaş süresi, hastalığın kuluçka süresi mutlaka yer almalıdır. Zira çalışan, ancak nasıl ve ne kadar sürede bulaştı̆̆ını bildiği virüse karşı kendisini koruyabilir.

Salgın özelinde verilmesi gereken İSG eğitimine ilişkin olarak gerçekleştirdiğimiz araştırmamızdaki çalışanların yalnızca \%15.43'ü işyerinde ek İSG eğitimleri verildiğini ifade etmiştir. Araştırmaya katılan işverenlerin ise sadece $\% 29,35$ ' $i$, işyerinde ek İSG eğitimleri düzenlediklerini belirtmiştir.

Yukarıda belirttiğimiz konuları kapsayan ek İSG eğitimi yanında, 6331 sayılı Kanun'un 15. maddesinde de belirtildiği üzere COVID-19'a yakalanan ve iyileşen bir çalışanın tedavisinin ardından işe dönüşünde salgın özelinde de ek İSG eğitimine tabi tutulması gerektiği açıktır (International Labour Organization, 2020c: 3). Yaptığımız araştırma kapsamında, işe güvenli dönüş bakımından oldukça önemli olan bu eğitime ilişkin olarak işverenlere/işveren vekillerine sorduğumuz "COVID-19'a yakalanıp iyileşen çalışanların işe dönüşlerinde işbaşı eğitimi veriyor musunuz?" sorusuna, araştırmaya katılanların \%22'si "Evet”; \%78'i ise ne yazık ki "Hayır" cevabını vermiştir.

Dünya Sağlık Örgütü tarafından sağlık, "sadece hastalıkların ve rahatsızlıkların olmayışı değil, bir bütün olarak fiziki, ruhi ve sosyal açıdan iyi olma hali" olarak tanımlanmıştır (World Health Organization, 2021). Bu itibarla, salgın kaynaklı ruhsal ve sosyal sorunların önlenmesi de işverenin İSG yükümlülükleri arasında yer alır. Bu nedenle işveren, çalışanların salgın kaynaklı sosyal damgalanmaya maruz kalmasını önlemeye yönelik önlemler de almakla yükümlüdür. Nitekim enfeksiyon riski yüksek olan işlerde çalışanların ve belirli 
ulusal, etnik kökenlerden gelenlerin salgın dönemlerinde sosyal damgalanmaya maruz kalabildikleri bilinen bir gerçektir (International Labour Organization, 2020a: 19; World Health Organization-United Nations International Children's Emergency Fund- International Federation of Red Cross and Red Crescent Societies, 2020). Buna karş1lık, araştırmalarımız sırasında, sadece bir çalışan, işyerinde ek İSG önlemi niteliğinde olmak üzere, sosyal destek servisinin oluşturulduğun ifade edilmiştir. Bu nedenle ülkemizde bu konuda da büyük eksiklik olduğu tespit edilmiştir.

Sosyal damgalanmanın önlenmesi ve sosyal damgalanmaya maruz kalan çalışanlar bakımından destekleyici çalışmaların yapılmasına ilişkin faaliyetleri ve bu konudaki eğitimleri organize etmek üzere işyerinde bir sosyal destek servisi kurulmalı; bu serviste çalışmak üzere söz konusu alanda uzman sosyal çalışmacı istihdam edilmelidir. Küçük ölçekli işletmeler bakımdan ise söz konusu hizmetin dış kaynaktan temin edilmesi dahi yeterli olacaktır.

6331 sayılı Kanun'un 13. maddesinde düzenlenen çalışmaktan kaçınma hakkı, iş sağlığ 1 ve güvenliğinin sağlanmasında çalışanlar bakımından ikinci bir kalkan görevi görmektedir (Akın, 2020: 34; Baycık, 2013: 118; Özdemir, 2014: 424). Bununla birlikte araştırmamız kapsamındaki çalışanların yalnızca \%13,72'si çalışmaktan kaçınma hakkının varlığı konusunda bilgi sahibi olduğunu ifade etmiştir. Söz konusu hakkın varlığı hakkında bilgi sahibi olanların \%29,9'u kamu kurumunda idari personel, \%28,5'i banka çalışanı, \%16,8'i üniversitede idari personel, \%12,4'ü ise akademisyendir.

Bu nedenle ülkemizde çalışmaktan kaçınma hakkının varlığına ilişkin farkındalık düzeyinin oldukça düşük olduğunu söylemek gerekir. Ayrıca araştırmamızda çalışanlara, "İ̧s sağllğ $l$ ve güvenliği önlemlerinin alınmadĭ̆ durumlarda, sahip olduğunuz hakları kullanmanızın işyerinde sıkıntı yaşamanıza yol açabileceğini düşünüyor musunuz?" sorusuna \%49,78 oranında "Evet", \%27,54 "Bilmiyorum" ve \%22,68 oranında "Hayır" yanıtı verilmiştir. Araştırmaya katılan akademisyenlerin \%48,4'ü, banka çalışanlarının \%58,8'i, kamu kurumunda çalışan idari personelin \%44,6's1, kamu kurumunda çalışan işçilerin \%28,9'u ve üniversitede çalışan idari personelin \%47,2'si salgın sürecinde sahip olduğu hakları kullanmasının işyerinde sıkıntı yaşamasına yol açacağını düşünmektedir. Görüldüğü üzere, araştırmamız kapsamındaki çalışanların yaklaşık \%50'si haklarını kullanmanın işyerinde soruna neden olacağını düşünmektedir. Oysaki alınacak İSG önlemlerinde hak bilincinin geliştirilmesi hedeflenmelidir. Bu nedenle, işveren tarafından verilmesi gereken eğitimlerin içeriğine çalışmaktan kaçınma hakkı, hakkın içeriği ve kullanım şartları da dahil edilmeli; çalışanların hakkın varlığı konusunda bilgi sahibi olması sağlanmalı; bu konuda farkındalık yaratılmalidir.

Salgın sürecinde üzerinde durulması gereken bir diğer önemli husus, işyerinde salgının yayılmasının önlenmesi ve hastalığa yakalananın mahremiyetinin korunması arasında makul bir dengenin kurulmasıdır. Bu amaçla, çalışanların sağlığına ilişkin bilgiler, işgücünü, çalışma arkadaşlarını, çalışma düzenini ve güvenliğini etkilemiyorsa talep edilmemeli ve çalışanın açık rızası olmadıkça diğer çalışanlarla paylaşılmamalıdır. İşyerinde COVID-19’a yakalanan bir çalışanın mevcut olması durumunda çalışanın kimliğine ilişkin bilgiler zorunlu olmadıkça paylaşılmamalı; diğer çalışanlarla yalnızca hastalığa yakalanan çalışanın kimlerle temaslı olduğunu tespit etmeye yarayacak -çalıştığı bölüm, çalıştığı kat gibi-niteliği gereği paylaşılması gerekli bilgiler paylaşılmalıdır. Paylaşma zorunluluğunun doğduğu hallerde de paylaşımın mümkün olduğunca temaslılarla sınırlı tutulmasına çalışılmalı (Kişisel Verileri Koruma Kurumu, 2020); bilgilendirme bu hususta yetkili işveren vekilince yapılmalıdır.

Çalışanların kişisel verilerinin korunması ve ISG arasındaki dengenin kurulabilmesi için, işyerinde işçilerin belirli gruplara ayrılarak aynı grubun çalışma ortamında, ara 
dinlenmelerinde, seyahat ederken ve yatakhanelerde de birlikte olması gibi temaslı tespitini kolaylaştıracak uygulamalara gidilmesi mümkündür (Health and Safety Executive, Goverment of The United Kingdom, 2020). Bununla birlikte, yaptığımız araştırmada "Sağllk gözetimi kapsamında sizden elde edilen verilerin sakl tutulacağı bilgisi sizinle paylaşıldı $m \imath$ ?" sorusuna, araștırmaya katılanların \%43,09'u konu hakkında bilgisinin olmadığ 1 , \%26,57'si "Evet", \%20,63'ü "Hayır” ve \%9,72'si "Kısmen” yanıtlarını vermişlerdir. Buradan, çalışanların büyük çoğunluğunun kişisel verilerinin güvenliğine ilişkin bilgi sahibi olmadığı sonucuna ulaşılması mümkündür. Ancak içinde bulunduğumuz çalışma ortamlarında dahi bu bilgilerin ne kadar hızlı paylaşıldığı ve yayıldığı dikkate alınacak olursa, hastalığa yakalanan çalışan bilgileri konusunda araştırmamızda vardığımız sonuçların gerçeği ne derece yansıttı̆̆ı düşündürücüdür.

\section{III- SALGIN ÖZELINDE ALINMASI GEREKEN EK İSG ÖNLEMLERI}

\section{A- Risk Değerlendirmesi ve Acil Durum Eylem Planı}

İşyerlerinde halihazırda risk değerlendirmesi yapılmış olması, COVID-19 salgınıyla mücadele kapsamında alınması gereken ISG önlemlerinin belirlenmesi ve gereğinin yerine getirilmesi açısından yeterli değildir. Yukarıda da açıklandığı üzere, İSG önlemlerinin ilk adımı ve belirleyicisi olan risk değerlendirmesinin salgın özelinde yenilenmesi ve bu doğrultuda bir acil durum eylem planı da hazırlanmalıdır. Bu şekilde oluşturulacak risk önleme ve kontrol sistemi, açık ve anlaşılır olmalı; hafif veya ortalama bir salgından şiddetli bir pandemiye kadar tüm ihtimallere karşı aşamalı bir biçimde ne yapılması gerektiğini içermelidir (World Health Organization, 2020a; U.S. Department of Labor Occupational Safety and Health Administration, 2020: 7-9).

Bunun yanında, salgın özelinde geliştirilen sistemin, işyerindeki mevcut İSG yönetim sistemi ile uyumlu olması ve mevcut sistemin içine entegre edilmesi gerektiği açıktır. Nihayetinde geliştirilen sistem, işyerinde çalışanlarla paylaşılmalı (Goverment of The United Kingdom, 2020) ve sürecin her aşamasında, ulusal otoriteler, sağlı hizmet sunucuları, acil durum hizmeti sağlayıcıları gibi işyeri dışı diğer paydaşlarla mümkün olduğunca iş birliği içinde hareket edilmelidir (International Labour Organization, 2020a: 8-12; Goverment of Canada, 2020). Sonucunda bilim ve teknolojinin gelmiş olduğu nokta itibariyle alınması gerekli olan tüm ek İSG önlemleri alınmalı ve etkin şekilde uygulanmalıdır.

İş kaynaklı risk, tehlikeli olayın meydana gelmesi "olasılığı"ndan ve bu olay nedeniyle insan sağlığının zarar görmesi halinde oluşacak zararın "ciddiyeti"nden oluşur (International Labour Organization, 2020a: 14). Alınması gereken ISG önlemleri, tehlikeli olayın meydana gelme olasılığının ve muhtemel bir zarar durumunda oluşacak zararın ciddiyeti değerlendirilerek tespit edilmelidir. Salgınla etkin mücadeleyi sağlayabilmek için bu değerlendirme sürecinin ve tespit edilen önlemlerin uygulanması aşamalarının tümünde, çalışanlar sürecin paydaşı ve etkin bir katılımcısı olmalıdır. Bu doğrultuda salgın özelinde bir pandemi kurulu (takımı) oluşturulmalı ve sürecin her aşaması bu kurul tarafından tartışılarak karara bağlanmalıdır. Söz konusu pandemi kurulu işyerindeki kıdemli yöneticilerden, danışmanlardan, işçi temsilcilerinden ve işyerinin sorumlu İSG personelinden oluşturulmalıdır (International Labour Organization, 2009: 16). Küçük ölçekli işletmeler bakımından ise salgın sürecinin yönetiminden sorumlu bir pandemi yetkilisinin atanması yeterlidir.

Çalışanların gelir güvencesinin sağlanmasında işletmelerin faaliyetini sürdürmeye devam edebilmesi gerekir. Sürdürülebilirliği temin amacıyla işyerinde acil durumlar bakımından geçerli hiyerarşi hatları belirlenmeli ve aynı görev için gerekli yetkiye sahip birden fazla kişi 
tayin edilmelidir. Bu sayede her bir çalışanın ikamesinin bulunması ve hastalık ya da salgın kaynaklı farklı bir makul nedenin varlığı halinde işleyişin sekteye uğraması engellenmelidir. Aynı amaca yönelik olarak pandemi kurulundaki çalışanlar, pandemi temsilcisi ve özellikle işyerinde kilit bir göreve sahip olan çalışanlar mümkün olduğunca birden çok beceriye (crosskilling) ya da birden çok eğitime (cross-training) sahip olanlar arasından seçilmelidir. Ayrıca işyerinde bir iletişim planlaması yapılmalı; acil iletişim numaraları, yönetici çalışanların acil durum iletişim bilgilerini de içerecek şekilde belirlenmeli ve işyerindeki çalışanlarla paylaşılmalıdır (International Labour Organization-International Finance Corporation, 2020; International Labour Organization, 2009: 21).

Çalışanların, salgının kaynağı olan virüse maruziyet riskini belirleyen unsurlardan biri de çalışılan sektör ve sektörde yapılan işin niteliğidir (U.S. Department of Labor Occupational Safety and Health Administration, 2020: 18). Bununla birlikte, hastalığa ilişkin bugüne kadar elde edilen veriler, bazı kimselerin hastalığa karşı daha kırılgan bir konumda olduğunu, hastalanma ve hastalık esnasında şiddetli semptomlar gösterme ihtimalinin daha fazla olduğunu ortaya koymaktadır. İşyerinde alınacak İSG önlemleri ve önlemler doğrultusunda düzenlenecek çalışma koşulları belirlenirken, söz konusu bireysel faktörler mutlak surette dikkate alınmalıdır. Bu doğrultuda hastalık karşısında en kırılgan olan kimseler aşağıda sayılmıştır (T.C. Sağlık Bakanlığı, 2020a; Canadian Centre of Occupational Health and Safety, 2020):

- 60 yaş üstü olanlar

- Ciddi kronik tıbbi rahatsızlıkları (Kalp hastalığı, hipertansiyon, solunum yoluna ilişkin kronik rahatsızlıklar) olan kişiler

- Bağışıklık sistemi baskılanmış kişiler (kronik kan hastalığı olanlar, kanser hastaları)

- İmmünsüpressif ilaç kullananlar (HIV/AIDS hastaları gibi)

- Kornea nakli hariç solid organ nakli, kemik iliği/kök hücre nakli yapılan hastalar

- Morbid obez olanlar (Vücut Kitle İndeksi VKİ> 40 kg/m2)

- Huzurevi, bakımevi gibi ortamlarda yaşayanlar

- Sağlık çalışanları

Burada belirtmek gerekir ki, gebelerde hastalığın etkisine ilişkin ise sınırlı nitelikte kanıt mevcuttur. Mevcut kanıtlar, gebelerin COVID-19 enfeksiyonu sonrası hastalık şiddetinin, gebe olmayan yetişkin COVID-19 vakalarına benzer olduğunu göstermektedir. Ayrıca gebelik esnasında COVID-19 ile enfeksiyonun fetüste olumsuz bir etkisi olduğunu ve gebelik esnasında COVID-19'un anneden bebeğe bulaştığını gösteren hiçbir veri yoktur.

\section{B- Damlacık Yayılımını ve Yakın Teması Önlemeye Yönelik Önlemler}

COVID-19 salgınına ilişkin yapılan değerlendirmelerde, salgın bakımından asıl bulaşma yolunun damlacık (flügge) ve dolayısıyla temas olduğu ortaya konmuştur. $\mathrm{Bu}$ nedenle işyerinde alınacak ek İSG önlemlerinin temelini, damlacık yayılımının ve temasın önlenmesi oluşturur. İşyerinde temel bulaşma yollarına ve bunlardan korunmaya ilişin bilgilendirici nitelikte afiş, broşür ve benzeri materyal, işyerlerinin girişine ya da rahat görünebilecek yerlere asılmalıdır (Goverment of Canada, 2020). İşyerlerinin girişinde ve belirli aralıklarla olmak üzere kolay ulaşılabilecek noktalarında el antiseptiği veya en az \% 70 'lik alkol içeren kolonya bulundurulmalıdır. Bunlar düzenli aralıklarla kontrol edilerek her zaman dolu olması 
sağlanmalıdır. COVID-19'a karşı yüzeyleri temizlemek ve dezenfekte etmek için sıklıkla kullanılan kimyasallardan bazılarının (dezenfektan mendil, sprey ve diğer temizleyicilerin içinde çoğunlukla bulunan dörtlü amonyum bileşikleri gibi) insan sağlığına zararlı etkileri olduğu ortaya konmuştur ${ }^{2}$. Bu nedenle, özellikle bu kimyasallar o işyerinde daha önce kullanılmamış veya az kullanılmışsa, çalışanlar bu kimyasalların doğru ve güvenli kullanımı konusunda uygun şekilde eğitilmeli, dezenfektanların riskleri ve maruziyet seviyeleri hakkında bilgilendirilmelidir.

Bulaşa neden olan damlacıkların yayılımının engellenmesi amacıyla çalışanların ağız ve burunlarını tamamen kapatacak șekilde maske takması sağlanmalı; bu önlem ara dinlenmelerinde de uygulanmalıdır. İşyerinde kullanım esnasında maske nemlendikçe ya da kirlendikçe değiştirmeye imkân sağlayacak miktarda maske tedarik edilmeli; çalışanlar maske değişimi esnasında ellerin temiz olması konusunda uyarılmalıdır. Belirtmek gerekir ki, temizlik çalışanları, bulaşık yıkayanlar, et ve et ürünleri ile paketlenmemiş gıda satışında çalışanlar haricindekilerin bir İSG önlemi niteliğinde olmak üzere eldiven takması önerilmemektedir. Zira eldivenin, bulaşa engel olacağı yönünde gerçekçi olmayan bir güven hissi yaratarak, COVID-19'un bulaşma ihtimalinin artırması ihtimali yüksektir. Eldiven kullanılması halinde ise, eldivenle yüzeylere dokunulmamalıdır. Temizlik çalışanlarının çalışırken maske ve eldiven takması sağlanmalıdır. Temizlik sonrasında maske ve eldivenler çıkarılarak, işyerindeki çöp kutusuna atılmalı; eller en az 20 saniye boyunca su ve sabunla yıkanmalıdır. Salgın boyunca işyerine, olağan döneme kıyasla daha fazla sayıda çöp kutusu yerleştirilmeli ve kutular sık sık boşatılarak atıklar tahliye edilmelidir (Health and Safety Executive, Goverment of The United Kingdom, 2020). İşyerinde masa, kapı kolu, telefon ve klavye gibi sıklıkla dokunulan yüzeylerin düzenli şekilde dezenfekte edilmesi sağlanmalı; tuvaletler dahil ortak alanlar düzenli olarak temizlenmelidir. Aynı şekilde emzirme odalarındaki sıklıkla temas edilen yüzeyler başta olmak üzere, emzirme odaları düzenli olarak temizlenmeli ve dezenfekte edilmelidir. Süt pompasına ya da sütün toplandığı şişeye dokunmadan önce ellerin yıkanması ve her kullanımın ardından pompanın sütle temas kısımlarının temizlenmesi gerektiği yönünde kadın işçilere eğitim verilmelidir (World Health Organization, 2020b). Eklemek gerekir ki, salgın dolayısıyla işyerinde artan temizlik faaliyetlerini yerine getirebilmek amacıyla işletmelerde dış kaynak kullanımına gidilmesi mümkündür (International Labour Organization, 2020a).

İşyerinde teması ve yoğunluğu engelleyebilmek amacıyla işyerinin dış kapısına, içeri girişleri engelleyecek nitelikte basit bir engel/uyarıcı koyulmalıdır. Bu uyarıcının kapının iki yanına tutturularak girişi engellemeyi sağlayan bir kordon ya da girişi bloke eden plastik duba, koli, kasa gibi bir materyal olması mümkündür. Hem kapı yüzeyiyle teması azaltmak hem de işyerinin daha iyi havalandırılmasını sağlamak için kapılar mümkün olduğunca açık tutulmalıdır. İşyerinde yoğunluğu önlemek amacıyla kişiler işyerine sıra ile alınmalı; sıra esnasında beklenilecek alanlar, kişilerarası mesafe en az bir buçuk metre olacak şekilde yer işaretleriyle belirlenmelidir. Çalışan ve müşteri sayısı toplamına göre işyerinin büyüklügü ve özelliği de dikkate alınarak metrekare başına işyerine alınabilecek kişi sayısı planlanmalı (4/6/8/10 metrekareye 1 kişi) ve insanlar içeriye bu sayıya göre kabul edilmelidir. Çalışanları koruyabilmek amaciyla mümkün olduğu takdirde tezgah ve müşteriler arasına doğrudan teması engelleyecek şeffaf bir bariyer yerleştirilmelidir. Müşterilerin işyerinde su hariç olmak üzere içecek ve yiyecek tüketmesine müsaade edilmemelidir. Kasa önünde yer işaretlemesi yapılarak bekleme esnasında müşteriler arasında en az 1,5 metre mesafe olması sağlanmalı (T.C. Sağlık Bakanlığı, 2020b), aynı mesafe çalışan ile müşteri arasında da muhafaza edilmelidir.

\footnotetext{
${ }^{2}$ Yapılan çalışmalar bu dezenfektanların, sperm sayımı ve yumurtlama süreçlerini olumsuz etkileyebileceğini, kronik obstrüktif akciğer hastalığı riskini artırabileceğini $(K O A H)$ ve astım semptomlarını tetikleyeceğini göstermektedir (International Labour Organization, 2020:27).
} 


\section{C- Sosyal Damgalanmayı Önlemeye Yönelik Önlemler}

Salgın dönemlerinde özellikle yüksek enfeksiyon riski olan işlerde çalışanların, virüs taşıyor olabilecekleri şüphesini içeren biçimde sosyal damgalanmaya maruz kalması mümkündür. Nitekim bu zamana kadar yaşanan salgınlardan elde edilen deneyimler, salgın sürecinde sosyal damgalanma ve ayrımcılığın yanı sıra fiziksel ve psikolojik şiddet ile tacizin artabildiğini göstermektedir (International Labour Organization, 2020a: 19). Ayrıca yalnızca yüksek enfeksiyon riski olan işlerde çalışanların değil; bazı etnik ya da ulusal kökenlerden gelenlerin de virüs taşıyor olabilecekleri şüphesini içeren şekilde sosyal damgalanma ve ayrımcılığa maruz kalındığı tespit edilmiştir (World Health Organization- United Nations International Children's Emergency Fund- International Federation of Red Cross and Red Crescent Societies, 2020).

Çalışanların işyerinde, belirtilen önyargılara dayalı sosyal damgalanmaya, toplumdan dışlanmaya, şiddete, tacize maruz kalmamaları ve ayrımcılığa uğramamaları için gerekli önlemler işverence alınmalıdır. Belirtmek gerekir ki, virüs taşıyor olduğu önyargısına bağlı şiddet yanında ayrıca, seyahat kısıtlamaları ve asli maddelerin temin edilememesi gibi nedenlerle bu kısitlamaları uygulayan kolluk personelinin ve asli hizmet ve malların satımı veya ulaşımı ile görevli olan çalışanların da şiddete maruz kalma riski salgın dönemlerinde artmaktadır. Aynı şekilde, iş teftiş personeli de çalışanların sağlığı açısından hayati tehlike içeren durumlarda işin durdurulması yaptırımını uyguladıkları takdirde şiddete maruz kalabilmektedir. İşyerinde değinilen risklerin önüne geçebilmek, şiddeti önlemek ve şiddete maruz kalan bir çalışan olduğu takdirde çalışanın rehabilitasyonunu sağlayabilmek amacıyla; sosyal destek birimleri kurulmalıdır. Ayrıca işverence verilme yükümlülüğü bulunan İSG eğitimlerinin sosyal damgalanmayı önleyecek bir içeriğe sahip olması da sağlanmalıdır (International Labour Organization, 2020a: 21).

\section{D- Çalışmaktan Kaçınma Hakkına İlişkin Bilgilendirme Yapılması}

İşyerlerinde alınan İSG önlemlerinin yeterli olmadığı durumlarda, çalışmaktan kaçınma hakkı hayati önem taşır. Bu nedenle salgınla mücadele bakımında da çalışanlara kendini koruma imkânı sağlayan çalışmaktan kaçınma hakkının önemini ayrıca vurgulamak gerekir. $\mathrm{Bu}$ doğrultuda çalışanlar, her birinin yakın ve ciddi tehlikenin varlığ 1 halinde çalışmaktan kaçınma hakkı olduğu konusunda bilgilendirilmeli; işveren tarafından verilmesi gereken İSG eğitiminin kapsamına söz konusu hak ve hakkın kullanım koşulları dahil edilmelidir.

Çalışmaktan kaçınma hakkı, yetersiz kalan İSG önlemleri karşısında çalışana tanınmış çok önemli bir haktır. Bununla birlikte çalışmaktan kaçınma hakkının kullanılması, işveren önlem alma yükümlülüğünü ortadan kaldırmamaktadır. Bu nedenle, işyeri yönetiminin sorumluluklarının ve taahhütlerinin yer aldığı bir beyan geliştirilip, bu beyanın işyerinde yayımlanması, işyerindeki ISG bilincinin gelişimine katkı sağlayacaktır. Ayrıca ulusal otoritelerce belirlenmiş algoritmalar doğrultusunda işyerinde virüs bulaşmış veya bulaşma şüphesi altında bir çalışanın mevcut olması durumunda ne yapılacağına ilişkin olarak işyerine özgü bir acil durum planı geliştirilmeli (International Labour Organization, 2020b; T.C. Aile, Çalışma ve Sosyal Hizmetler Bakanlığı-İş Sağlığı ve Güvenliği Genel Müdürlüğü, 2020; T.C. Sağlık Bakanlığı, 2020c) ve çalışanlara verilecek eğitimin kapsamına söz konusu planın içeriği de dahil edilmelidir.

\section{E- Önlemleri Toplumsal Cinsiyet Bakış Açısıyla Belirleme Gerekliliği}

Toplumsal cinsiyete dayalı iş bölümü nedeniyle krizlerden ve dolayısıyla salgınlardan erkekler ve kadınlar farklı şekilde etkilenmektedir. Nitekim aynı işi yapan kadınların erkeklere göre daha düşük ücretlerle çalıştırılabildiği, çoğunlukla kadınların daha güvencesiz 
işlerde çalıştırıldığı, özel sigortaya sahip olan kadınların erkeklere oranla daha az olduğu bilinmektedir. Bu nedenle, işyerinde salgın nedeniyle alınacak önlemlerin etkin olabilmesi için önlemleri belirlerken toplumsal cinsiyet bakış açısına sahip olunmalı; cinsiyet körü bir yaklaşımdan kaçınılmalıdır (United Nations Women, 2020).

$\mathrm{Bu}$ doğrultuda olmak üzere belirtmek gerekir ki, araştırmalarımız sonucunda elde edilen verilere göre, salgın döneminde ISSG önlemi olarak uzaktan çalışmaya geçilmesini talep eden çalışanların $\% 62,8$ 'i, çalışma sürelerinin esnekleştirilmesini talep eden çalışanların $\% 63,1$ 'i, dönüşümlü çalışmaya geçilmesini talep edenlerin ise \%62,2'si kadındır. Uzaktan çalışma, dönüşümlü çalışma ya da çalışma sürelerinin esnekleştirilmesini talep eden çalışanların çoğunluğunun kadın olmasının nedeninin, kadına yüklenen toplumsal cinsiyet rolü olduğu değerlendirilmektedir. Zira toplumsal cinsiyete dayalı iş bölümünde ev işleri ve bakım sorumlulukları kadına özgülenmiş olduğundan, kadının aynı zamanda ev dışında çalışıyor olması kadının toplumsal cinsiyet rolünün içeriğinde herhangi bir değişiklik yaratmamaktadır. Bu nedenle önlemler gibi çalışma koşullarında da kadınların mevcut durumunu değiştirecek düzenlemeler yapılmalı; çocuk sahibi olan (özellikle tek ebeveyn olan) ya da başkaca bakım sorumluluğu bulunan kadınlar, salgın dönemleri gibi tüm kriz dönemlerinde nakit desteği, kreş, özel sigorta gibi uygulamalarla daha fazla desteklenmelidir (United Nations Women, 2020).

\section{F- İşletme Devamlılık Politikası-Planı ${ }^{3}$ Oluşturma Gerekliliği}

Salgın sürecinin getirdiği ekonomik zorluklar, işletmelerin sürdürülebilirliği açısından sorunlar yaratmakta ve işten çıkarmalara neden olabilmektedir. İşini kaybeden çalışanlar, genellikle İSG anlamında çok daha yetersiz olan küçük işletmelerde ya da kayıt dışı olarak güvencesiz şekilde çalışmakta ve salgın karşısında çok daha korumasız hale gelmektedir. Zira dünya genelinde çalışanların yalnızca $1 / 5$ 'i işsizlik yardımlarından yararlanabilmektedir (International Labour Organization, 2020: 7). Bu nedenle işletmenin sürdürülebilirliğini sağlamaya yönelik bir işletme devamlılık politikası-planı oluşturulması veya var olan planın salgın özelinde tekrar gözden geçirilmesi, salgın sürecinde çalışanların korunması bakımından önem arz etmektedir. Nitekim işletme devamlılık politikası; işverenlere kriz karşısında esneklik sağlarken, iş̧̧ilerin de işlerini kaybetmelerini, dolayısıyla kayıı dışı ve/veya güvencesiz sektöre kaymalarını engeller. Belirtmek gerekir ki, işletme devamlılık planı veya içerisindeki acil durum eylem planı, bir salgının işçiler üzerinde yaratabileceği olası ruh sağlığı sonuçlarını ve sosyal sonuçları da ele almalıdır (Instutition of Occupational Safety and Health, 2020; International Labour Organization, iki yüz bir 2).

İşletme devamlılığının ve çalışanların gelir güvencesinin sağlanmasında işçi ve işveren kuruluşları önemli bir role sahiptir. Bu kuruluşlar hem üyeleriyle hem de birbirleriyle dayanışma içinde olarak işletmenin devamlılığı ve gelir güvencesinin sağlanması yönünde aktif rol oynamalıdır. Bu doğrultuda ve alınacak İSG önlemleri bakımından bir mutabakata varmak amacıyla, işverenlerin ve çalışanların üye olduğu kuruluşlar arasında sosyal diyalog geliştirilmeli ve ortak kararlar alınarak bu kararların gereğinin yerine getirilmesi için çalışılmalıdır (International Organisation of Employers-International Trade Union Confederation, 2020).

Ülkemiz özelinde konuya ilişkin olarak TÜRK-İŞ, HAK-İŞ VE TİSK tarafindan yapılan ortak bir açıklama olmakla birlikte, söz konusu açıklama devlete yöneltilen ortak taleplere

\footnotetext{
${ }^{3}$ İşletme devamlılık politikası-planı, herhangi bir kriz karşısında işletmenin hem ekonomik yönden esnekleşmesini hem de çalışanların gelir güvencesini sağlayıcı önlemlerle birlikte söz konusu krizle mücadeleyi ve krizi atlatmayı sağlayıcı tüm tedbirleri içeren yöntem ve sistem belgesidir (International Labour Organization, 2020a: 32-34; International Labour Organization, 2009: 48).
} 
ilişkin olup, ne yazık ki, işletme devamlılığı ve gelir güvencesine yönelik örgütsel vaatlere ilişskin bir içeriğe sahip değildir (Türkiye İşçi Sendikaları Konfederasyonu-Hak İşçi Sendikaları Konfederasyonu-Türkiye İşveren Sendikaları Konfederasyonu, 2020). Bu itibarla, sosyal tarafların kuruluşlarından çok daha etkin ve etkili bir politika oluşturmaları beklenmektedir.

\section{G- İşe Güvenli Dönüşün Sağlanması}

Salgın kapsamında alınacak ek İSG önlemlerinin kapsamına, hastalık bulaşan bir çalışanın iyileşmesinin ardından işe dönüşünde izlenmesi gereken yol da dahil edilmelidir. İyileşmesinin ardından işe dönen çalışana, içeriğinde salgının bulaşma yolları ve salgından korunmak amacıyla alınması gereken önlemlerin de yer aldığı bir ek İSG (işbaşı) eğitimi verilmelidir. Belirtmek gerekir ki, doğrulanmış veya şüpheli COVID-19 vakalarının bilgisini kayıt altında tutmak, virüsün işyerlerinde nasıl yayıldığını analiz etmede ve işe dönüş protokollerinin ihlallerini ve önleyici/koruyucu tedbirlerdeki eksiklikleri tespit etme noktasında önemlidir. Bu nedenle işyerindeki COVID-19 vakaları kayıt altına alınmalı ve bu kayıtlardan elde edilen veriler işe güvenli dönüş planının belirlenmesinde göz önünde bulundurulmalıdır (International Labour Organization, 2020c: 2). Ancak açıklandığı üzere, bu kayıtlar gizli tutulmalı; sadece sağlığın korunması amacıyla gerektiği ölçüde ve gerektiği kişilerle paylaşılmalıdır.

İşe güvenli dönüş adımları belirlenirken işyerinde etkili bir sosyal diyalog mekanizması oluşturulmalı; çalışanlar, COVID-19 pandemisiyle ilgili gereksinimler doğrultusunda durumu tartışmak için toplantılar düzenlemekte özgür kılınmalıdır. Ayrıca işyerinde faaliyet gösteren alt işverenlerle, İSG protokollerinin uygulanmasına ve koordinasyonuna azami önem gösterilmeli; alt işverenler kendi işyerleri bakımından çalışanlarını sürecin etkin katılımcısı yapma konusunda teşvik edilmelidir. İşe güvenli dönüşün sağlanması amacıyla işletme/işyeri yönetimi tarafindan acil telefon numaraları da dahil olmak üzere çalışanların güncel iletişim bilgilerine sahip olunmalıdır. Çalışanlar sağlıkları için ciddi ve yakın bir tehlikenin olduğu iş durumlarında çalışmaktan kaçınma hakları olduğu ve bu hakkın şartları konusunda bilgilendirilmelidir. Yöneticiler de rol model olarak hareket etmek, güvenli ve sağlıklı davranışları teşvik etmek ve destekleyici bir ortam sağlamak üzere ayrıca eğitilmelidir (International Labour Organization, 2020c: 2; International Labour Organization, 2001).

\section{SONUÇ}

Salgın koşullarında işyerinde alınan önlemler, çalışanların korunması bakımından işverenin yükümlülüğ̈ olmakla birlikte, toplum sağlığının tesisi bakımından da büyük bir öneme sahiptir. 120K619 sayılı TÜBİTAK projesi kapsamında salgın esnasında faaliyetine devam etmiş bakanlık, üniversite, banka, çağrı merkezi ve sigorta şirketi çalışanı dokuz yüz doksan sekiz kişiye ve bu işyerlerinin işveren/işveren vekili iki yüz bir kişiye uygulanan anketten elde edilen veriler doğrultusunda, işyerlerinin çoğunluğunda salgına yönelik olmak üzere ek İSG önlemlerinin alındığı sonucuna ulaşılmıştır. Bu kapsamda işyerlerinde çoğunlukla alınan önlemler, COVID-19 hakkında bilgilendirici materyallerin işyerine asılması, çalışana mail yoluyla gönderilmesi, işyerinin uygun yerlerine el antiseptiği, kolonya vb. yerleştirilmesi gibi el hijyenine yönelik tedbirler ve sosyal mesafe sağlanması gibi işyerindeki insan yoğunluğunu azaltmaya yönelik önlemlerdir. Ayrıca yaş, kronik hastalık gibi kişileri salgına karşı daha kırılgan hale getiren bireysel faktörlere ilişkin önlemler alınarak risk grubunda olan çalışanların uzaktan çalışmaya geçirildiği, yıllık izin sürelerinin bu dönemde kullandırıldığı ya da ücretsiz izne çıkarıldığı tespit edilmiştir. 
Çalışmamız kapsamındaki araştırmalarımız sonucunda, salgın karşısında işyerinde alınması gereken önlemlerin bazılarının, işyerlerinin çoğunluğunda göz ardı edildiği sonucuna varılmıştır. Zira işyerlerinde salgın özelinde bir risk değerlendirmesi yapılmadığı, acil durum eylem planı hazırlanmadığı, pandemi kurulu oluşturulmadığı/pandemi temsilcisi atanmadığı, salgın özelinde İSG eğitimi verilmediği, sosyal damgalanmayı engellemeye yönelik faaliyetlerde bulunulmadığı araştırmalarımızda elde ettiğimiz endişe verici sonuçlar olmuştur.

COVID-19 salgınında ve benzeri diğer salgınlarda, İSG önlemlerinin tespitindeki ilk temel adımı oluşturan risk değerlendirmesinin salgın özelinde yenilenmesi gerektiği açıktır. Bu şekilde belirlenen risklere göre acil durum eylem planı yeniden hazırlanarak yürürlüğe koyulmalı ve işyerindeki tüm çalışanların planın içeriğinden haberdar olması sağlanmalıdır. Çalışanlara, yapılan iş ya da işyeri kaynaklı bulaşın önlenmesi amacına dönük İSG eğitimi verilmeli, verilen eğitimin kapsamına çalışmaktan kaçınma hakkının kullanım şartları, çalışanların kişisel verilerinin gizliliğine ilişkin bilgilendirme ve sosyal ayrımcılığın önlenmesine ilişkin bir içerik de dahil edilmelidir. Salgına karşı işyerinde alınması gereken önlemler ve çalışma koşulları toplumsal cinsiyet bakış açısıyla değerlendirilmeli ve cinsiyetler arası maddi eşitlik esas alınmalıdır. Çalışanların COVID-19 sürecinde de kişisel verilerinin gizliliği ihlal edilmemeli, işyerinde COVID-19'a yakalanan bir çalışanın mevcut olması halinde, çalışanın kimliğine ilişkin bilgiler zorunlu olmadıkça ve zorunlu olsa da gerekli olan kişiler dışındakilerle paylaşılmamalı; paylaşma zorunluluğunun doğduğu hallerde, paylaşımın mümkün olduğunca temaslılarla sınırlı tutulmasına çalışılmalı; bilgilendirme bu hususta yetkili işveren vekilince yapılmalıdır.

\section{Kaynakça}

Akın, L. (2020). COVID-19'un İș İlişkilerine Olası Etkileri. Çimento İşveren Dergisi. 34(3). 16-71.

Baycık, G. (2013). Çalışanların İş Sağlığı ve Güvenliğine İlişkin Haklarında Yeni Düzenlemeler. Ankara Barosu Dergisi. 2013(3). 105-170.

Berkowitz, D. (2020). Worker Safety \& Health During COVID-19 Pandemic: Rights \& Resource. National Employment Law Project. [https:// www . nelp . org / publication / workersafety - health - during - COVID - 19 -pandemicrights-resources/]. (Erişim: 23 Kasım 2020).

Canadian Centre of Occupational Health and Safety (2020). Coronavirus, OSH Answers Fact Sheets, Which Occupations are at Risk. [Coronavirus: OSH Answers (ccohs.ca)]. (Erişim: 14 Aralık 2020).

Goverment of Canada (2020). Risk Mitigation Tool for Workplaces/Businesses Operating During the COVID-19 Pandemic. [COVID-19: Risk Mitigation Tool For Workplaces / Businesses Operating During the PandemicCanada.ca]. (Erişim: 14 Aralık 2020).

Goverment of The United Kingdom (2020). Staying COVID-19 Secure in 2020 Notice,
Staying COVID-19 Secure in 2020 notice. [GOV.UK (www.gov.uk)]. (Erişim: 14 Aralık 2020).

Health and Safety Executive, Goverment of The United Kingdom (2020). What to Include in Your COVID-19 Risk Assessment. [Health and Safety Executive (hse.gov.uk)]. (Erişim: 14 Aralık 2020).

Instutition of Occupational Safety and Health (2020). Coronavirus, How Businesses Have Adapted to COVID-19 [ https:// iosh . com / coronavirus \# emergencyplanningadvice ] . (Erişim: 03 Kasım 2020).

International Labour Organization (2001). Planning and Management Systems and Training to Prepare For a Safe Return to Work. [https://www.ilo.org/wcmsp5/groups/public/- - ed_protect/---protrav/---safework / documents / normativeinstrument / wcms 107727 . pdf ] . (Erişim: 04 Kasım 2020).

International Labour Organization (2009). Prevent and Prepare For Pandemics/Business Continuity Planning/Guidelines for Small and Medium-Sized Enterprises. [https:// www . ilo . org/wcmsp5/groups/public/---asia/---robangkok /documents/publication/wcms_142747.pdf]. (Erişim: 03 Kasım 2020). 
International Labour Organization (2012). Stress Prevention at Work Checkpoints, Practical Improvements for Stress Prevention in The Workplace. [ https : / / www . ilo . org / wcmsp5/ groups / public / - - - dgreports / - - - dcomm /--publ/documents/publication/wcms_168053.pdf] . (Erişim: 04.11.2020).

International Labour Organization (2020a). In the Face of a Pandemic: Ensuring Safety and Health at Work. [https://www.ilo.org/wcmsp5 / groups / public / - - - ed _ protect /---protrav/--safework/documents/publication/wcms_742463 .pdf]. (Erişim: 03 Kasım 2020).

International Labour Organization (2020b). Prevention and Mitigation of COVID-19 at Work, Action Check List. [https://www.ilo. org/ wcmsp5 / groups / public / --- ed _ protect / --protrav /---safework/documents/instructionalmaterial /wcms_741813.pdf]. (Erişim: 03 Kasım 2020).

International Labour Organization (2020c). A Safe and Healthy Return to Work During the COVID-19 Pandemic. [https://www.ilo.org/ wcmsp5/groups/public/---ed_protect/---protrav / --- safework / documents / briefingnote / wcms _ 745549.pdf]. (Erişim: 04 Kasım 2020).

International Labour Organization-International Finance Corporation (2020). Compilation of Guidelines on COVID-19 Transmission, Prevention and Management and the Best Practices in the Workplace. [https:// betterwork.org / wp-content / uploads/2020/04/BWI_COVID_guidance_eng_ web.pdf]. (Erişim: 02 Kasım 2020).

International Organisation of EmployersInternational Trade Union Confederation (2020). Joint Statement on COVID-19. [https://www.ilo.org/wcmsp5/groups/public/--ed_dialogue/---actrav/documents/genericdocument / wcms_739522.pdf]. (Erişim: 04 Kasım 2020).

Kişisel Verileri Koruma Kurumu (2020). Kamuoyu Duyurusu. [https://www.kvkk.gov.tr/ Icerik/6721/Kamuoyu-Duyurusu-COVID-19-ile -Mucadele-Surecinde-Kisisel-Verilerin-KorunmasiKanunu-Kapsaminda-Bilinmesi-Gerekenler].

(Erişim: 03 Aralık 2020).

Özdemir, E. (2014). İş Sa ̌̆lı̆̆ ve Güvenliğ Hukuku. İstanbul: Vedat Kitapçıllk.

Süzek, S. (2020). Iss Hukuku (Genel EsaslarBireysel İs Hukuku). İstanbul: Beta Yayınevi.

T.C. Aile, Çalışma ve Sosyal Hizmetler Bakanlığı-İşs Sağlığı ve Güvenliği Genel Müdürlügüü (2020). İşyerlerinde Yeni Tip Koronavirüsten Korunma Tedbirleri. [https:// ailevecalisma.gov.tr/covid19]. (Erişim: 03 Aralık 2020).
T.C. Sağlık Bakanlığ (2020a). COVID-19 Hastalığ 1 İçin Risk Grubunda Olan Kronik Hastalıklar. [https://dosyamerkez.saglik.gov.tr/Eklenti /37458,covid-19-hastaligi-iustyazi47a0af17-2c 6a-45a6-88c5-eaeff2d6b8b8pdf.pdf?0\&_tag1= C3D6A395CBA0D50C452C3B20B286BDC5 D1C496DB]. (Erişim: 03 Aralık 2020).

T.C. Sağlık Bakanlığı (2020b). COVID-19 Salgın Yönetimi ve Çalışma Rehberi. [https://covid19 .saglik.gov.tr/Eklenti/39265/0/covid19salginyo netimivecalismarehberipdf.pdf]. (Erişim: 03 Aralık 2020).

T.C. Sağlık Bakanlığı. (2020c). COVID-19 (SARSCOV-2 Enfeksiyonu) Temaslı Takibi, Salgın Yönetimi, Evde Hasta İzlemi ve Filyasyon. [https://covid19.saglik.gov.tr/TR-66339/temasli -takibi-salgin-yonetimi-evde-hasta-izlemi-vefilyasyon.html]. (Erişim: 04 Aralık 2020).

Türkiye İşçi Sendikaları Konfederasyonu-Hak İşci Sendikaları Konfederasyonu-Türkiye İşveren Sendikaları Konfederasyonu (2020). Türk-İş, Hak-İş ve TíSK'ten Ortak Açılama. [TISSK | Duyurular (tisk.org.tr)]. (Erişim: 26 Aralık 2020).

United Nations Women (2020). Checklist for COVID-19 Response by UN Women Deputy Executive Director Åsa Regnér, Checklist for COVID-19 response by UN Women Deputy Executive Director Åsa Regnér | UN Women Headquarters. [https://www.unwomen.org/en/ news/stories/2020/3/news-checklist-for-covid19-response-by-ded-regner]. (Erişim: 03 Aralık 2020).

U.S. Department of Labor Occupational Safety and Health Administration (2020). Guidance on Preparing Workplaces for COVID-19. [https://www.osha.gov/Publications/OSHA399 0.pdf]. (Erişim: 24 Nisan 2020).

World Health Organization (2020a). Coronavirus Disease (COVID-19): Health and Safety in the Workplace. [https://www.who.int/news-room/qa-detail/q-a-tips-for-health-and-safety-at-theworkplace-in-the-context-of-covid19?gclid $=\mathrm{Cj}$ 0KCQjwlvT8BRDeARIsAACRFiW_RznggPz0 2YfUpxNS2Mk5UP5rUClda6Lluawq3o4iP1tN qGzj5K0aAjIxEALw_wcB]. (Erişim: 04 Kasım 2020).

World Health Organization (2020b). Coronavirus Disease (COVID-19): Breastfeeding. [https://www .who.int/emergencies/diseases/novel-coronavirusikiyüzbir9/question-and-answers-hub/q-a-detail/ coronavirus-disease-covid-19-breastfeeding]. (Erişim: 04 Kasım 2020). 
World Health Organization (2021). What is the WHO Definition of Health? Frequently Asked Questions. [https://www.who.int/about/whowe-are/frequently-asked-questions]. (Erişim: 11 Ocak 2021).

World Health Organization- United Nations International Children's Emergency FundInternational Federation of Red Cross and Red Crescent Societies (2020). A Guide to Preventing and Addressing Social Stigma. [https ://www.who.int/docs/default-source/coronaviruse/ covid19-stigma-guide.pdf]. (Erişim: $04 \mathrm{Kasım}$ 2020). 
